\title{
Correction to Pakeliani, Lachat, Blohmé, Kobayashi, Chaykovska, Pfammatter, Puippe, Veith, and Pecoraro (2020)
}

In the original version of this article that was published online September 23, 2019, and in print in volume 49, issue 1, of the journal, Gilbert Puippe, Institute of Diagnostic and Interventional Radiology, University Hospital Zurich, Zurich, Switzerland, was listed as 7th author. He asked for his name to be removed from the list of authors. The version of record that has been available online under DOI 10.1024/0301-1526/a000820 from January 2020 onwards reflects that request.

\section{Reference}

1. Pakeliani D, Lachat M, Blohmé L, Kobayashi M, Chaykovska L, Pfammatter T, Puippe G, Veith FJ, Pecoraro F, Improved technique for sheath supported contralateral limb gate cannulation in endovascular abdominal aortic aneurysm repair VASA. 2020 Jan;49(1):39-42. https://doi.org/10.1024/0301$1526 / a 000820$

Published online 01.03.2021 